\title{
Minimally Invasive Approach in a Child's Renal Hydatid Disease: Laparoscopic Partial Nephrectomy
}

\author{
Çocuk Hastada Renal Hidatik Kistte Minimal İnvaziv Girişim: Laparoskopik Parsiyel \\ Nefrektomi
}

\author{
(1) Yusuf Alper Kara, (1) Ergun Ergün, (1) Engin Yılmaz, (1) Beytullah Yağız, (1) İsmet Faruk Özgüner \\ Dr. Sami Ulus Health, Practice and Research Center, Department of Pediatric Surgery, Ankara, Turkey
}

\section{Abstract}

Echinococcosis is a parasitic disease which is caused by Echinococcus granulosus. Renal infection in children is rare. Besides medical treatment, open surgery, laparoscopy and retroperitonoscopy have been started to be used increasingly. A 13-year-old girl with a kidney cyst hydatid applied to the hospital and laparoscopic excision was performed, and there was no complication in 12-month follow-up period. Laparoscopic partial nephrectomy is a safe and feasible method for kidney cyst hydatid disease.

Key Words: Children, Echinococcosis, Laparoscopy

\section{Öz}

Ekinokokkoz, Echinococcus granulosus tarafından oluşturulan parazitik bir hastalıktır. Renal enfeksiyon çocuklarda nadiren görülür. Medikal tedavinin yanı sıra; açık cerrahi, laparoskopi ve retroperitoneoskopi artan oranlarda kullanılmaktadır. On üç yaşında kız hasta renal kist hidatik nedeniyle hastaneye başvurdu ve laparoskopik eksizyon uygulandı. Takip eden 12 aylık süreçte herhangi bir komplikasyon görülmedi. Laparoskopik parsiyel nefrektomi çocuklarda renal kist hidatik tedavisinde güvenli ve kullanışı bir seçenektir.

Anahtar Kelimeler: Çocuklar, Ekinokokkoz, Laparoskopi

\section{Introduction}

Echinococcosis is a parasitic disease which is caused by Echinococcus granulosus (1). Liver and lung are the most commonly infected organs but kidney, ovaries, brain, psoas muscle, bladder, lymph nodes and heart may be affected from the disease as well (1). Renal infection in children is rare, accounting $1.9 \%$ of all echinococcosis cases (2). It is suggested that left kidney involvement is more common than right and lower pole is the most common site (3). Besides medical treatment, open surgery is traditional method of treatment but minimal invasive options as laparoscopy and retroperitonoscopy are started to be used increasingly (3). It is aimed to present laparoscopic excision of left renal cyst with partial nephrectomy in 13-year-old girl.

\section{Case Report}

13-year-old girl who was operated because of left pulmonary cyst hydatid was applied to the hospital with left renal lower pole cyst which was revealed in routine abdominal ultrasound imaging. The cyst's size was $4.5 \times 3 \mathrm{~cm}$ and did not decrease in size during 3 months with Albendazole. All of the blood tests were normal and the patient did not have any symptoms. Ultrasound revealed a cyst with membrane formation; considered as a hydatid cyst. Magnetic resonance imaging (MRI) was performed and revealed a cyst which is $4 \mathrm{~cm}$ in diameter in a strict relation with kidney tissue (Figure 1). Although the lesion was thought of a hydatid cyst in ultrasonography; the MRI couldn't make differential diagnose and because of this condition, total 


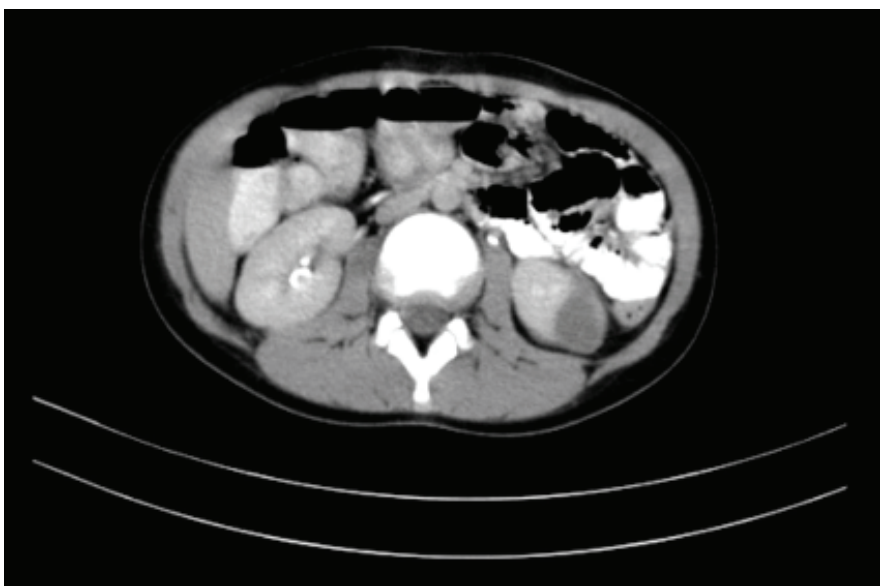

Figure 1: MRI of the cyst in left kidney

MRI: Magnetic resonance imaging

excision of the cyst was planned. Laparoscopic excision was performed while the child was left decubitus position. A 12 $\mathrm{mm}$ port for camera and endobag insertion was placed through the umbilicus and two $5 \mathrm{~mm}$ working ports were placed in left upper and left lower quadrants. Retroperitoneal cavity explored and the left kidney and infrarenal cyst was shown. The cyst was held with an atraumatic instrument and it was figured out that the border between the kidney and the cyst was not certain. As a result of this condition; total excision of the cyst with minimal excision of renal parenchymal tissue surrounding the cyst were planned. At the upper border of the cyst, the surrounding renal tissue was dissected by using hook and vessel sealing cautery. No demarcation line seen at the lower pole of the kidney. Closer intervention to the renal hilum was avoided and only minimal renal parenchymal tissue which was attached to the cyst. The cyst was taken out via Endobag (Medtronic ${ }^{\circledR}$ ). No bleeding was seen after excision and the appearance of the kidney was natural. No complication seen in 12 months follow up period.

\section{Discussion}

Laparoscopic removal of the cyst seems to be feasible and safe in selected cases. In present case, partial nephrectomy was performed to assure the cyst remain intact. It may be suggested that to protect kidney function and also to remove the cyst completely it was the best choice.

Definitive hosts of Echinococcus' are dogs and intermediate hosts are sheep (4). Humans, on the other hand are accidental intermediate hosts and usually infected by egg contaminated soil or animal contact $(1,3)$.

The most common sites of infection in human body are liver and lungs (4). After these, kidney seems to be the third most common infection site and it consists 2-3\% of all Echinococcus infections (1). In children the renal involvement is even rarer; consisting $1.9 \%$ of all cases (2). In such rare disease, it may be difficult to have a consensus of treatment methods but increasingly use of endoscopic surgery in last 30 years makes it possible to approach these kinds of cystic diseases in a more minimally invasive fashion. The total removal of the cyst is essential to avoid morbidities associated with hydatid cyst or other possible underlying diseases (5). Laparoscopy is a beneficial alternative for open surgical approach because of less pain in the postoperative period, less activity restriction and earlier return to daily routine.

Differential diagnose of the renal cyst would take much time and there was the risk of rupture or spread. So, these risks weren't taken and the cyst was excised totally. In patient with Echinococcosis, the treatment always requires a proper combination of drugs and surgery. Albendazole is the most common antihelmintic agent for Echinococcosis treatment because of better penetration capability into the cyst (6). Among the actual surgical options; open surgery, endoscopic surgery and puncture-aspiration-injection and re-aspiration are feasible with certain advantages and risks. The conventional option is open resection in cyst hydatid (3). Some authors suggest that endoscopic surgery is not the primary choice of surgery because of the risks of spillage and secondary hydatis but in selected cases and experienced hands, endoscopic surgery may be performed safely as a minimally invasive choice (3).

In conclusion, it may be suggested that, primary objectives of renal cyst hydatid treatment should be total cure without recurrence, excision of the cyst without pillage and protecting renal function as possible via the most minimal invasive method. In this case, laparoscopic partial nephrectomy was performed in line with these purposes. To ensure excising the cyst intact, nearly 2 millimeters of kidney tissue was removed with the cyst from the border of kidney.

Laparoscopic partial nephrectomy is a safe and feasible method for kidney cyst hydatid disease.

\section{Ethics}

Informed Consent: Informed consent was obtained from patient's parent.

Peer-review: Externally peer-reviewed.

\section{Authorship Contributions}

Concept: Y.A.K., E.E. Design: Y.A.K., E.E., I.F.Ö. Data Collection or Processing: Y.A.K., E.E, E.Y., B.Y. Analysis or Interpretation: Y.A.K., E.E, E.Y., B.Y. Literature Search: Y.A.K., E.E., I...Ö. Writing: Y.A.K., E.E, E.Y., B.Y., I.F.Ö,

Conflict of Interest: No conflict of interest was declared by the authors.

Financial Disclosure: The authors declared that this study received no financial support. 


\section{References}

1. Sarmast $A H$, Sherwani $A Y$, Dangroo $S A$, et al. An isolated renal hydatid cyst in a 6-year-old child: A rare case report. J Res Med Sci. 2014;19:279-281.

2. Durakbasa CU, Tireli GA, Sehiralti $V$, et al. An audit on pediatric hydatid disease of uncommon localization: Incidence, diagnosis, surgical approach, and outcome. J Pediatr Surg. 2006;41:1457-1463.

3. Rexiati M, Mutalifu A, Azhatiet B, et al. Diagnosis and Surgical Treatment of Renal Hydatid Disease: A Retrospective Analysis of 30 Cases. PLoS One. 2014;9:e96602.

4. Cevik M, Boleken ME, Kurkcuoglu IC, et al. Pulmonary hydatid disease is difficult recognized in children. Pediatr Surg Int. 2014;30:737-741.

5. Bensghir M, Bouhabba N, Traore A, et al. Anaphylactic shock during hydatid cyst surgery. Saudi J Anaesth. 2012;6:161-164.

6. Aydogdu B, Sander S, Demirali O, et al. Treatment of spontaneous rupture of lung hydatid cysts into a bronchus in children, J Pediatr Surg. 2015;50:14811483. 